\title{
Dysregulation of Striatal Dopamine Receptor Binding in Suicide
}

\author{
Megan L Fitzgerald ${ }^{* 1,2,3}$, Suham A Kassir ${ }^{2,3}$, Mark D Underwood ${ }^{1,2}$, Mihran J Bakalian ${ }^{2}$, J John Mann ${ }^{1,2}$ and \\ Victoria Arango ${ }^{1,2}$
}

'Department of Psychiatry, Columbia University, New York, NY, USA; ${ }^{2}$ Division of Molecular Imaging and Neuropathology, New York State

Psychiatric Institute and Columbia University, New York, NY, USA

\begin{abstract}
Inconsistent evidence implicates disruptions of striatal dopaminergic indices in suicide and major depression. To determine whether there are alterations in the striatal dopamine system in suicide, we conducted a quantitative autoradiographic survey of dopamine transporter (DAT; $\left[^{3} \mathrm{H}\right]$ mazindol), DI receptor $\left(\left[^{3} \mathrm{H}\right] \mathrm{SCH} 23390\right)$, and D2 receptor $\left(\left[{ }^{3} \mathrm{H}\right]\right.$ sulpiride) binding in the dorsal striatum postmortem from matched suicides and controls. Axis I and axis II psychiatric diagnosis, recent treatment history, and early life adversity (ELA) were determined by psychological autopsy. Mean DAT, D2, and DI receptor binding did not differ in suicide. However, there was a positive correlation between DI and D2 receptor binding in the dorsal striatum of control subjects $\left(R^{2}=0.31, p<0.05\right)$ that was not present in suicides $\left(R^{2}=0.00, p=0.97\right)$. In suicides and controls with reported ELA, there was no correlation between striatal DAT and DI receptor binding $\left(R^{2}=0.07, p=0.33\right)$, although DAT and DI receptor binding was positively correlated in subjects with no report of ELA $\left(R^{2}=0.32, p<0.05\right)$. After controlling for age, there were no significant ELA-related mean differences. Binding of DI receptors and DAT throughout the striatum correlated negatively with age (DI receptor: $R^{2}=0.12, p<0.05$; DAT: $R^{2}=0.36, p<0.00$ I). There appears to be an imbalance in dopaminergic receptor and transporter expression related to suicide that differs from that associated with ELA or age. Neuropsychopharmacology (2017) 42, 974-982; doi:10.1038/npp.2016.124; published online 10 August 2016
\end{abstract}

\section{INTRODUCTION}

Suicide can be a devastating end point of psychiatric disease and is the tenth leading cause of death in the United States (Xu et al, 2016). Dopamine signaling critically modulates motivational and emotional processing as well as reward association, and these are altered in mood disorders and in suicide (Dunlop and Nemeroff, 2007). However, whether striatal dopamine receptor or transporter expression is altered in major depressive disorder (MDD) and/or suicide is unclear.

The dorsal striatum, which includes the caudate nucleus and putamen, is the convergent target of glutamatergic cortical and thalamic inputs whose activity is modulated by dopaminergic efferents from the substantia nigra, and is comprised predominantly of GABAergic medium spiny neurons (MSNs) (Beckstead et al, 1979; Gerfen, 1985). Dopamine D1 and D2 receptors are expressed primarily postsynaptically on dendritic shafts and spines of distinct subgroups of MSNs (Shen et al, 2008; Thibault et al, 2013), whereas the dopamine transporter (DAT) is localized chiefly on nigrostriatal axon terminals (Torres et al, 2003).

*Correspondence: Dr ML Fitzgerald Department of Psychiatry, Columbia University, I05I Riverside Drive, NYSPI Unit 42, Room 2908, New York, NY 10032, USA, Tel: + I 6467747569,

Fax: + | 6467747589, E-mail: mf2982@cumc.columbia.edu

${ }^{3}$ These authors contributed equally to this work.

Received I March 2016; revised 3 June 2016; accepted 4 July 2016; accepted article preview online 12 July 2016
While some studies report altered indices of dopaminergic signaling in mood disorders and suicide (Dougherty et al, 2006; Laasonen-Balk et al, 1999; Pitchot et al, 2001; Ruiz et al, 1992), others find unaltered striatal dopamine receptor binding sites in depression and/or suicide (Bowden et al, 1997; Suhara et al, 1992); for review, see Savitz and Drevets (2013). The present study, therefore, was designed to test the primary hypothesis that dopamine receptor and/or DAT expression is altered in suicide.

Striatal dopamine may also be disrupted by environmental factors that are implicated in suicide, such as early life adversity (ELA) (Bruffaerts et al, 2010). Striatal dopamine release is related to low parental care and increased cortisol levels in response to a psychosocial stressor in humans (Pruessner et al, 2004) while in rodent models, maternal separation induces changes in striatal DAT levels (Meaney et al, 2002). Behaviorally, ELA is correlated with increased risk of substance abuse, mood disorders, and suicide (Enoch, 2011; Johnson et al, 2002; MacMillan et al, 2001; Molnar et al, 2001). However, the neurobiological effect of ELA on striatal dopaminergic signaling in humans has not yet been reported in the context of suicide.

The current study utilized quantitative autoradiography of coronal sections through the dorsal striatum of suicides and non-psychiatric controls to quantify DAT, D1, and D2 receptor binding postmortem. $\left[{ }^{3} \mathrm{H}\right]$ mazindol was used to label DAT, $\left[{ }^{3} \mathrm{H}\right]-\mathrm{SCH} 23390$ the D1 receptor, and $\left[{ }^{3} \mathrm{H}\right]$ sulpiride the D2 receptor. Reports of ELA and psychiatric diagnoses were collected for all subjects at psychological autopsy. 


\section{MATERIALS AND METHODS}

\section{Subjects}

Brain tissue was provided by the Allegheny County coroner (Pennsylvania) or the New York City medical examiner offices in accordance with city and county regulations. Protocols were approved by the Institutional Review Board for biomedical research of the New York State Psychiatric Institute or the University of Pittsburgh. The coroner or medical examiner determined the cause of death.

A psychological autopsy was conducted by interviewing at least one informant per case as described by Kelly and Mann (1996) and Mann (2000). The clinical diagnoses were determined using the SCID and DSM-IV criteria, and were confirmed at a consensus conference with the psychologist raters and a group of investigators, including psychiatrists. An Axis I diagnosis of MDD was present in 11 of the 17 suicides. Medications prescribed 3 months antemortem were reported at psychological autopsy. All control subjects underwent a similar psychological autopsy and were psychiatrically normal at the time of death although three of the controls had a lifetime diagnosis (Table 1). The presence of ELA was determined at psychological autopsy. ELA was defined as the occurrence of one or more of the following events before the age of 15: obstetric complications or birth problems, separation from either parent for more than 6 consecutive months, separation or divorce of the deceased parents, having been adopted, having lived in a foster home or orphanage, or a history of physical and/or sexual abuse. ELA was present in 6 of the control subjects and 10 of the suicides. An affirmative response was required to be placed in the ELA category, and subjects were not placed in this category in absence of this information.

Each subject underwent neuropathological examination and toxicological screening. Drug status at the time of death was determined by analysis of peripheral fluids (blood/urine or vitreous) and brain. Individuals with a history of HIV, stroke, central nervous system disease, or cerebral trauma were excluded from the study.

Brains were collected at autopsy. The right hemisphere of each brain was sectioned into $1.5-\mathrm{cm}$ coronal blocks that were immersed in liquid Freon- $12\left(-20^{\circ} \mathrm{C}\right.$, dichlorodifluoromethane, Suva) while lying flat on a glass slide, and then stored at $-80^{\circ} \mathrm{C}$ before sectioning. Sixty frozen $20 \mu \mathrm{m}$ coronal sections at the level of the ventral striatum were collected serially using a large format cryostat (Cryopolycut, Leica, Germany) and thaw-mounted onto acid-cleaned, gelatin-subbed 3" X 5" glass slides. Slides were desiccated and stored at $-20^{\circ} \mathrm{C}$ for $24 \mathrm{~h}$ and $-80{ }^{\circ} \mathrm{C}$ thereafter. Nissl substance staining was performed on one section every $200 \mu \mathrm{m}$. Brain sections were coded and all further processing was conducted by personnel masked to cause of death.

Control and suicide subjects were matched for age (controls: $45.3 \pm 21.1$ years, suicide: $44.7 \pm 22.8$ years), sex (14 males and 4 females in each group), and as closely as possible for postmortem interval (PMI; controls: $15.8 \pm 5.4 \mathrm{~h}$, suicides: $19.7 \pm 4.1 \mathrm{~h}$ ). Although PMI was significantly longer for suicides $(f=2.5, p<0.05)$, average brain $\mathrm{pH}$ did not significantly differ between suicides $(\mathrm{pH}=6.63 \pm 2.7)$ and controls $(\mathrm{pH}=6.51 \pm 0.19)$. Individual subject data and causes of death are listed in Table 1.

\section{Quantitative Autoradiography of $\left[{ }^{3} \mathrm{H}\right] \mathrm{SCH} 23390$}

$\left[{ }^{3} \mathrm{H}\right] \mathrm{SCH} 23390$ was used to quantitate dopamine D1 receptor binding as described by Przedborski et al (1991). Sections were placed in a desiccation chamber for $30 \mathrm{~min}$ at room temperature before pre-incubation for $30 \mathrm{~min}$ at $21^{\circ} \mathrm{C}$ in $50 \mathrm{mM}$ Tris buffer ( $\mathrm{pH} 7.4$ ) containing $120 \mathrm{mM} \mathrm{NaCl}$, $5 \mathrm{mM} \mathrm{KCl}, 2 \mathrm{mM} \mathrm{CaCl}_{2}$, and $1 \mathrm{mM} \mathrm{MgCl}_{2}$. Sections were then incubated in the same buffer at $23^{\circ} \mathrm{C}$ for $90 \mathrm{~min}$ with $2 \mathrm{nM}\left[{ }^{3} \mathrm{H}\right] \mathrm{SCH} 23390$ and $50 \mathrm{nM}$ ketanserin tartrate (SigmaAldrich, St, Louis, MO) to mask binding to serotonin 2A receptors. Non-specific binding was determined in near adjacent sections with $10 \mu \mathrm{M}$ cis-(z)-flupentixol dihydrochloride (RBI, MA). Following radioligand incubation, sections were washed twice for $10 \mathrm{~min}$ in ice-cold incubation buffer and then briefly dipped in ice-cold deionized water. Sections were then quickly dried and transferred to a vacuum desiccator until exposure.

Dried slides were then assembled in X-ray film cassettes and exposed to tritium-sensitive film (Hyperfilm; Amersham, Uppsala, Sweden) with tritium standards (American Radiolabeled Chemicals, St. Louis, MO) for 5 weeks. Cassettes containing films and sections were stored at $4{ }^{\circ} \mathrm{C}$ in a box containing desiccant throughout the period of exposure.

\section{Quantitative Autoradiography of $\left[{ }^{3} \mathrm{H}\right]$ mazindol}

Autoradiography of $\left[{ }^{3} \mathrm{H}\right]$ mazindol $(23 \mathrm{Ci} / \mathrm{mmol}$; NEN, MA) to dopamine reuptake sites in the striatum (Przedborski et al, 1991) was performed as described above, with the minor modifications as follows. Briefly, sections were pre-incubated in $50 \mathrm{mM}$ Tris $\mathrm{HCl}$ buffer ( $\mathrm{pH}$ 7.9) containing $120 \mathrm{mM} \mathrm{NaCl}$ and $5 \mathrm{mM} \mathrm{KCl}$ for $30 \mathrm{~min}$ at room temperature. Sections were then incubated in the same buffer with $4 \mathrm{nM}\left[{ }^{3} \mathrm{H}\right]$ mazindol for $60 \mathrm{~min}$ at $4{ }^{\circ} \mathrm{C}$. Non-specific binding was determined using $100 \mu \mathrm{m}$ nomifensin. Sections were then washed and desiccated, and exposed with tritium standards to Hyperfilm (Amersham) for 4 weeks before developing.

\section{Quantitative Autoradiography of $\left[{ }^{3} \mathrm{H}\right]$ sulpiride}

Autoradiography of D2 receptor binding sites was performed using $\left[{ }^{3} \mathrm{H}\right]$ sulpiride $(70 \mathrm{Ci} / \mathrm{mmol}$ : NEN) as described by Jastrow et al (1984), with minor modifications. The D2 receptor has up to a 100 -fold greater selectivity for sulpiride than the D3 receptor (Vallone et al, 2000). Sections were preincubated at room temperature for $30 \mathrm{~min}$ in $50 \mathrm{mM}$ Tris$\mathrm{HCl}$ buffer (pH 7.7) containing $120 \mathrm{mM} \mathrm{NaCl}$ and $5 \mathrm{mM} \mathrm{KCl}$ before incubation in the same buffer with $5 \mathrm{nM}\left[{ }^{3} \mathrm{H}\right]$ sulpiride and $0.1 \%$ ascorbic acid for $1 \mathrm{~h}$ at room temperature. Nonspecific binding was determined using $1 \mu \mathrm{M}$ Butaclamol (RBI). Following washes and desiccation, slides were exposed to Hyperfilm (Amersham) for 12 weeks.

\section{Radioligand Binding Analysis}

Regionally specific receptor binding density was analyzed using imaging software (MCID Elite version 7, Imaging Research, Canada, now Interfocus Imaging, UK). Images were acquired using a 12-bit digital CCD camera mounted on a light stand containing a wide-area diffused light source. 
Table I Summary of Postmortem Cases

\begin{tabular}{|c|c|c|c|c|c|c|c|c|c|c|c|c|c|c|c|c|}
\hline Pair & Group & Axis I diagnosis & Axis 2 diagnosis & $\begin{array}{l}\text { Childhood } \\
\text { adversity }\end{array}$ & Age & Sex & Race & Manner of death & Brain toxicology & Blood toxicology & Prescribed $^{\mathbf{a}}$ & PMI & $\mathrm{pH}$ & DAT $^{\mathbf{b}}$ & $\mathrm{DI}^{\mathrm{b}}$ & D2 ${ }^{\mathbf{b}}$ \\
\hline \multirow[t]{2}{*}{ । } & Control & Alcohol abuse, ADHD & None & Yes & 16 & Male & $\begin{array}{l}\text { African } \\
\text { American }\end{array}$ & $\begin{array}{l}\text { Motor vehicle } \\
\text { accident, passenger }\end{array}$ & Barbiturates & None & None & 9 & 6.5 & $x$ & $x$ & \\
\hline & Suicide & $\begin{array}{l}\text { MDD, Conduct } \\
\text { disorder, ADHD, } \\
\text { Marijuana abuse }\end{array}$ & None & Yes & 13 & Male & White & Ingestion of bleach & None & None & None & 18 & 6.4 & $x$ & $x$ & \\
\hline \multirow[t]{2}{*}{2} & Control & $\begin{array}{l}\text { Alcohol abuse, } \\
\text { Conduct disorder }\end{array}$ & None & Yes & 18 & Male & $\begin{array}{l}\text { African } \\
\text { American }\end{array}$ & Stabbing (homicide) & None & None & None & 13 & 6.5 & $x$ & $x$ & $x$ \\
\hline & Suicide & MDD & $\begin{array}{l}\text { Avoidant personality } \\
\text { disorder, obsessive/ } \\
\text { compulsive }\end{array}$ & Yes & 17 & Male & White & Gunshot wound & None & None & None & 15 & 6.8 & $x$ & $x$ & $x$ \\
\hline \multirow[t]{2}{*}{3} & Control & None & None & Yes & 18 & Male & Hispanic & Cardiovascular & None & None & None & 14 & 6.7 & $x$ & $x$ & $x$ \\
\hline & Suicide & None & $\begin{array}{l}\text { Antisocial } \\
\text { personality disorder }\end{array}$ & Yes & 18 & Male & Hispanic & Hanging & None & Marijuana & None & 15 & 6.8 & $\times$ & $x$ & $x$ \\
\hline \multirow[t]{2}{*}{4} & Control & None & None & No & 24 & Male & Hispanic & Pulmonary embolism & None & None & None & 12 & 6.6 & $x$ & $x$ & $x$ \\
\hline & Suicide & $\begin{array}{l}\text { Bipolar disorder, } \\
\text { Marijuana abuse }\end{array}$ & $\begin{array}{l}\text { Borderline } \\
\text { personality disorder }\end{array}$ & Yes & 24 & Male & White & Drowning & Lidocaine & Lidocaine, Lithium & $\begin{array}{l}\text { Lithium, } \\
\text { Haloperidol }\end{array}$ & 21 & 5.9 & $x$ & $x$ & $x$ \\
\hline \multirow[t]{2}{*}{5} & Control & None & None & No & 43 & Male & White & Cardiovascular & None & None & None & 23 & 6.1 & $x$ & $x$ & \\
\hline & Suicide & Schizophrenia & None & No & 41 & Male & White & Fall from height & None & None & Haloperidol & 22 & 6.4 & $x$ & $x$ & \\
\hline \multirow[t]{2}{*}{6} & Control & None & None & No & 66 & Male & White & Cardiovascular & None & None & None & 19 & 6.5 & $x$ & $x$ & $x$ \\
\hline & Suicide & None & $\begin{array}{l}\text { Schizoid personality } \\
\text { disorder }\end{array}$ & No & 63 & Male & Hispanic & Hanging & None & None & None & 17 & 6.7 & $x$ & $x$ & $x$ \\
\hline \multirow[t]{2}{*}{7} & Control & Past cocaine abuse & $\begin{array}{l}\text { Borderline } \\
\text { personality disorder }\end{array}$ & Yes & 25 & Male & White & $\begin{array}{l}\text { Accidental carbon } \\
\text { monoxide inhalation }\end{array}$ & Cocaine & Carbon monoxide & None & 18 & 6.7 & $x$ & $x$ & $x$ \\
\hline & Suicide & MDD & $\begin{array}{l}\text { Avoidant personality } \\
\text { disorder }\end{array}$ & Yes & 19 & Male & $\begin{array}{l}\text { African } \\
\text { American }\end{array}$ & Gunshot wound & None & None & None & 24 & 6.9 & $x$ & $x$ & $x$ \\
\hline \multirow[t]{2}{*}{8} & Control & None & None & No & 30 & Female & $\begin{array}{l}\text { African } \\
\text { American }\end{array}$ & Cardiovascular & None & None & None & 8 & 6.4 & $x$ & $x$ & \\
\hline & Suicide & $\begin{array}{l}\text { Schizoaffective } \\
\text { disorder, past } \\
\text { alcohol, cocaine, } \\
\text { and marijuana abuse }\end{array}$ & None & Yes & 26 & Female & Hispanic & Hanging & None & None & None & 18 & 6.9 & $x$ & $x$ & \\
\hline \multirow[t]{2}{*}{9} & Control & None & None & No & 73 & Male & White & CNS & None & None & None & 11 & 6.2 & & & $x$ \\
\hline & Suicide & MDD & Other & No & 77 & Male & White & Gunshot wound & None & None & None & 13 & & & & $x$ \\
\hline \multirow[t]{2}{*}{10} & Control & None & None & Yes & 37 & Male & $\begin{array}{l}\text { African } \\
\text { American }\end{array}$ & Cardiovascular & None & None & None & 15 & 6.8 & $x$ & $x$ & $x$ \\
\hline & Suicide & MDD & $\begin{array}{l}\text { Obsessive/ } \\
\text { compulsive }\end{array}$ & Yes & 40 & Male & White & Hanging & None & Acetaminophen & $\begin{array}{l}\text { Zolpidem, } \\
\text { Sertraline }\end{array}$ & 20 & 6.8 & $x$ & $x$ & $x$ \\
\hline \multirow[t]{2}{*}{11} & Control & None & None & No & 58 & Male & White & Cardiovascular & Lidocaine & Lidocaine & None & 22 & 6.6 & $x$ & $x$ & $x$ \\
\hline & Suicide & MDD & None & No & 62 & Male & White & Drowning & None & None & Lorazepam & 21 & 6.4 & $x$ & $x$ & $x$ \\
\hline
\end{tabular}


Table I Continued

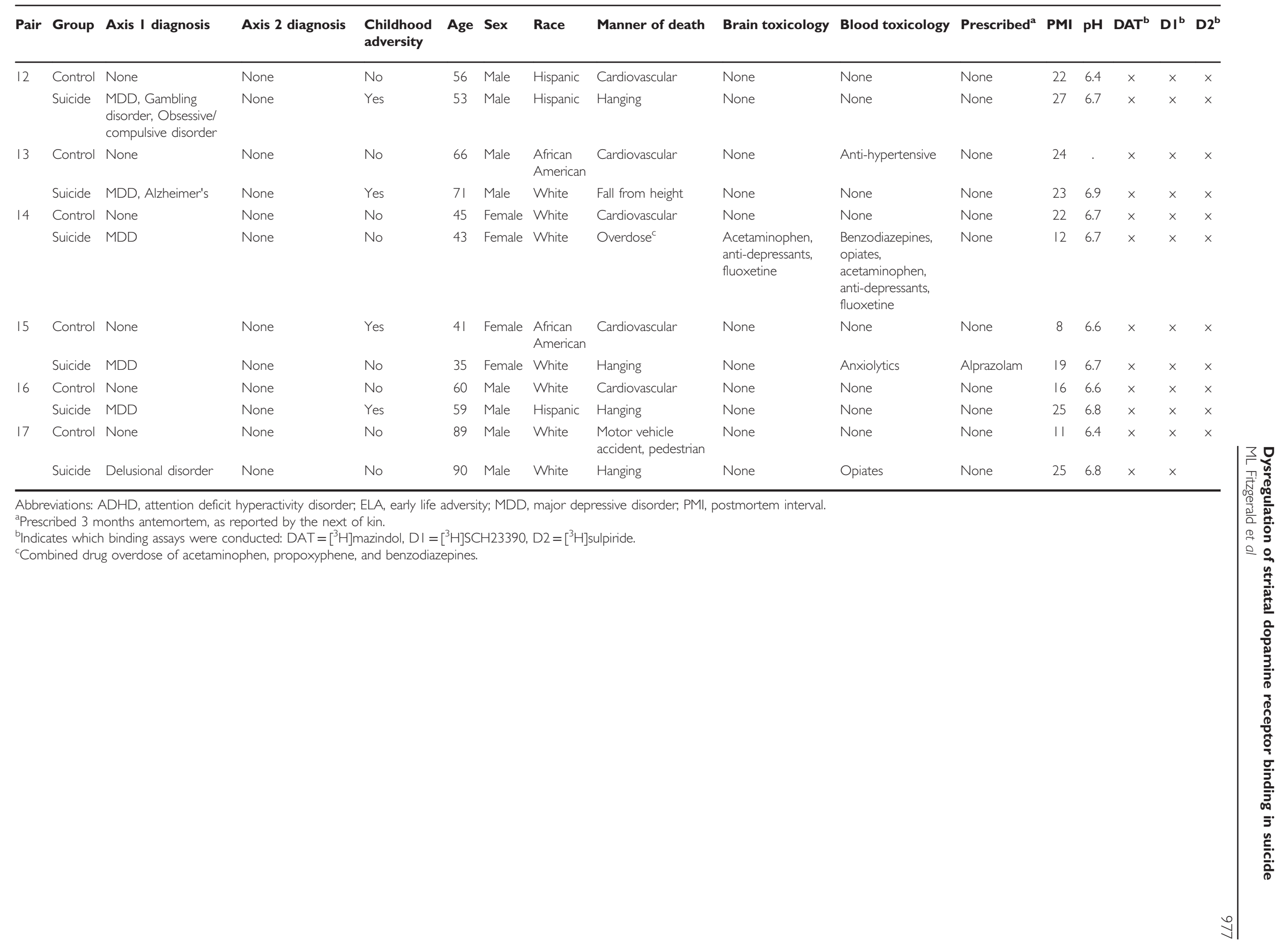




\section{a}

Dopamine transporter (DAT)

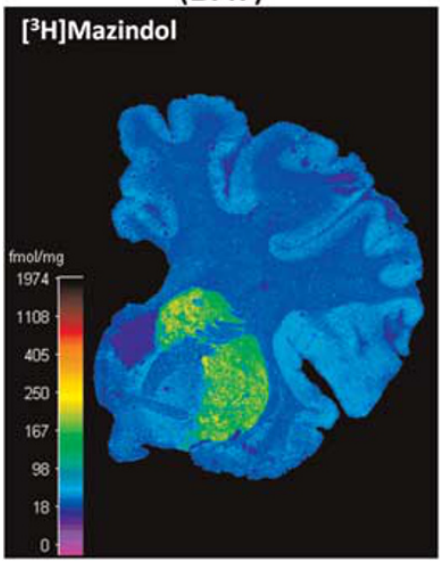

b

D1 receptor

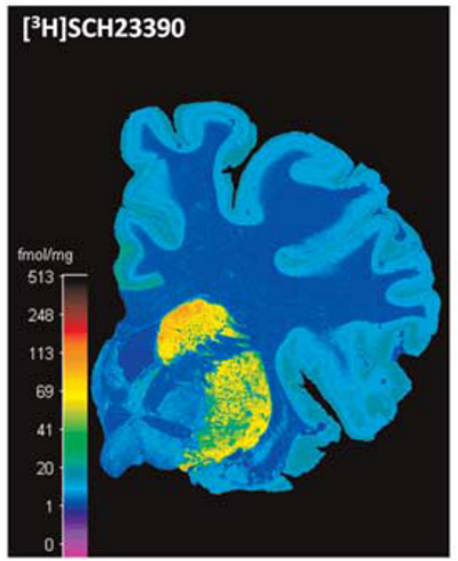

c D2 receptor

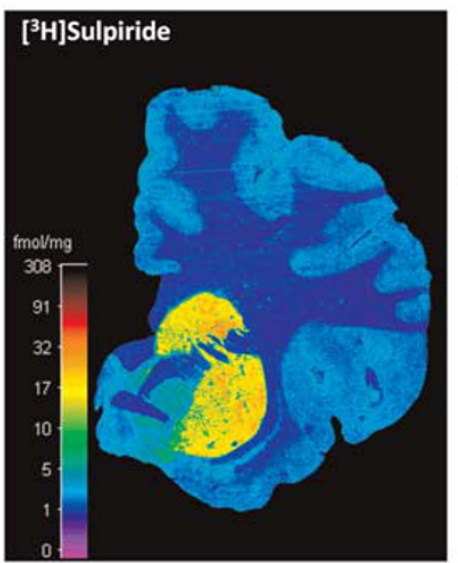

d

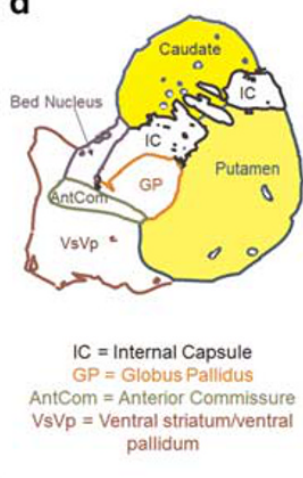

Figure I Representative heat-mapped autoradiographs and regions sampled. (a) DAT binding was quantified using $\left[^{3} \mathrm{H}\right]$ mazindol, (b) DI receptor binding with $\left[{ }^{3} \mathrm{H}\right] \mathrm{SCH} 23390$, and (c) D2 binding with $\left[{ }^{3} \mathrm{H}\right]$ sulpiride. Scale bars are in fmol/mg. (d) Regions sampled are outlined. The caudate and putamen (highlighted in yellow) comprises the dorsal striatum, which was analyzed in this study.

The camera output was first digitally normalized to a flat field of illumination. The output was also calibrated for absolute area measurements (in $\mathrm{mm}^{2}$ ). The radioisotope standard (ART-123, American Radiolabeled Chemicals), which was exposed to the same film as the sections, was also sampled. The sampled values, in relative optical density (ROD) units, were plotted against the known tissue equivalents of the standards values (in fmol/mg tissue) and a curve was fitted to the values, providing quantitation of the receptor density in units of $\mathrm{fmol} / \mathrm{mg}$ tissue for sampled anatomical regions of interest. Sectors incubated for total binding and for non-specific binding were imaged and aligned with each other in separate image channels. Regions of interest were then defined as a contour on the total binding image channel.

Sampling the total binding image region simultaneously sampled both total and non-specific channels within the same contour, providing an area-weighted mean of specific ligand binding that is anatomically registered (total - non-specific $=$ specific binding at that region). The caudate nucleus, putamen, internal capsule, bed nucleus of the stria terminalis, globus pallidus, anterior commissure, and ventral striatum/ventral pallidum were then identified, outlined by hand (as illustrated in Figure 1), and sampled. The identification of the region and the sample contour were verified by a second anatomist. Image analysis was conducted by investigators blind to group assignment. SPSS computer software (IBM) was used for statistical analysis of radioligand binding and linear regression analyses. Tissue was not always available for ventral striatal regions, and, therefore, for this study, only data from the dorsal striatal regions (caudate and putamen, highlighted in yellow in Figure 1) were included in the data analysis. Dorsal striatal tissue availability for each individual subject is shown in Table 1.

\section{Statistical Analyses}

All statistical comparisons, except correlation coefficient comparisons, were made using untransformed raw data.
Comparisons of mean DAT, D1, and D2 receptor binding were carried out using unpaired $t$-tests with Welch's correction. $P$-values and Welch-corrected $t$-values are reported. Statistical significance was determined at $P<0.05$. To determine the relationships between dopamine receptor binding in suicides and controls and to test the hypotheses that dopamine binding is correlated with age or ELA, linear regression analyses were carried out. $R^{2}$ and $P$-values are reported. A Fisher's r-to-z transformation was used to calculate a $z$-value to measure the significance of the difference between correlation coefficients.

\section{RESULTS}

\section{DAT, D1, and D2 Receptor Binding Does Not Differ Between Suicides and Controls in the Dorsal Striatum}

No significant differences in $\left[{ }^{3} \mathrm{H}\right] \mathrm{SCH} 23390,\left[{ }^{3} \mathrm{H}\right]$ mazindol, or $\left[{ }^{3} \mathrm{H}\right]$ sulpiride binding were observed between suicides and matched controls (Figures 2a and c). Mean dorsal striatal binding of the DAT ligand $\left[{ }^{3} \mathrm{H}\right]$ mazindol binding was $100.0 \pm 26.6 \mathrm{fmol} / \mathrm{mg}$ in controls and $99.3 \pm 25.6$ in suicides $(t=0.07, p=0.95)$. Mean binding of the D1 antagonist $\left[{ }^{3} \mathrm{H}\right] \mathrm{SCH} 23390$ was $48.9 \pm 14.2 \mathrm{fmol} / \mathrm{mg}$ in controls and $46.9 \pm 14.0 \mathrm{fmol} / \mathrm{mg}$ in suicides $(t=0.41, p=0.69)$, and mean binding of the D2 receptor antagonist $\left[{ }^{3} \mathrm{H}\right]$ sulpiride was $12.0 \pm 4.7 \mathrm{fmol} / \mathrm{mg}$ in controls and $12.0 \pm 4.0 \mathrm{fmol} / \mathrm{mg}$ in suicides $(t=0.02, p=0.98)$. There were furthermore no mean differences in DAT, D1, or D2 receptor binding between suicides with MDD and controls.

There were also no significant differences in striatal $\left[{ }^{3} \mathrm{H}\right]$ mazindol, $\left[{ }^{3} \mathrm{H}\right]$ sulpiride, or $\left[{ }^{3} \mathrm{H}\right] \mathrm{SCH} 23390$ binding between subjects diagnosed with $\mathrm{MDD}$ and those who were not. Mean dorsal striatal DAT radioligand $\left[{ }^{3} \mathrm{H}\right]$ mazindol binding was $100.0 \pm 6.0$ in non-MDD subjects and $98.83 \pm 7.6$ in subjects with $\mathrm{MDD}(t=0.13, p=0.90)$. In non-MDD subjects, mean binding of D1 ligand $\left[{ }^{3} \mathrm{H}\right] \mathrm{SCH} 23390$ was $44.51 \pm 5.3$ and in MDD subjects 49.47 $\pm 2.7 \quad(t=0.84$, $p=0.27)$. Mean binding of $\left[{ }^{3} \mathrm{H}\right]$ sulpiride, the D2 receptor radioligand, was $12.66 \pm 1.0$ in subjects without $\mathrm{MDD}$ and 


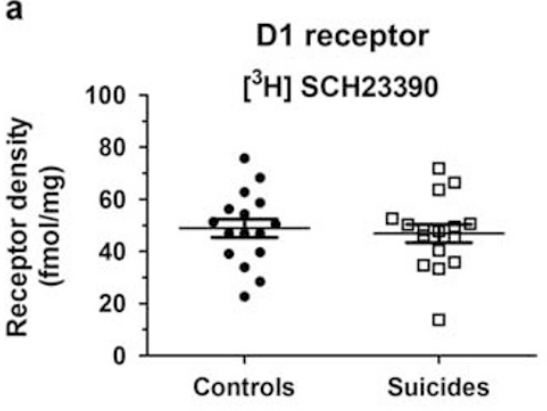

b

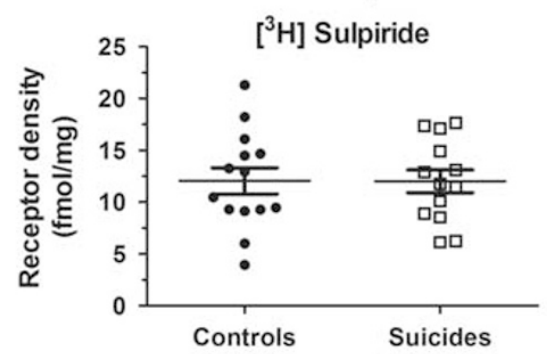

C

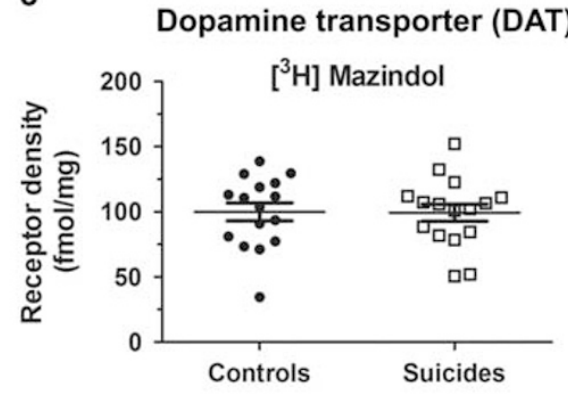

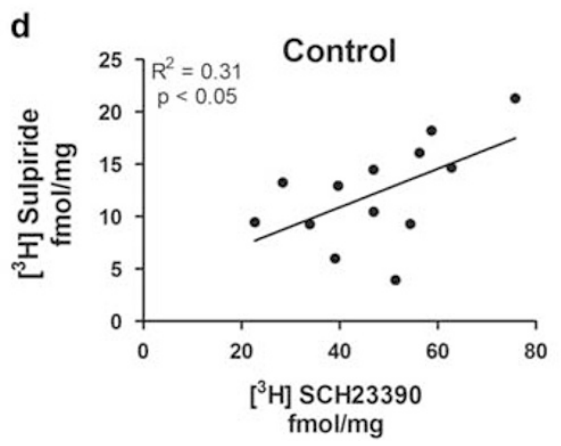

e

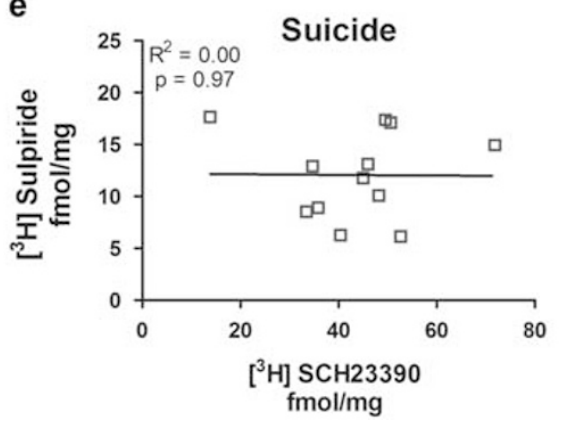

Figure 2 There is no difference in mean striatal DI, D2, and DAT radioligand binding between suicides and controls, but the correlation of striatal DI and D2 receptor binding levels is disrupted in suicide. (a) DI antagonist $\left[{ }^{3} \mathrm{H}\right] \mathrm{SCH} 23390$ binding is similar between controls and suicides $(t=0.4 \mathrm{I}, p=0.69)$, as is (b) D2 antagonist $\left.{ }^{3} \mathrm{H}\right]$ sulpiride $(t=0.02, p=0.98)$ and (c) DAT ligand $\left[{ }^{3} \mathrm{H}\right]$ mazindol $(t=0.07, p=0.95)$. (d) There is a significant positive correlation $\left(R^{2}=0.31, p<0.05\right)$ between $\mathrm{D} \mid$ and D2 receptor binding in control dorsal striatum that does not exist in (e) the dorsal striatum of suicides $\left(R^{2}=0.00\right.$, $p=0.97)$.

$11.65 \pm 1.2$ in subjects with $\operatorname{MDD}(t=0.65, p=0.52)$. No sex differences were observed in binding.

\section{D1 Receptor and D2 Receptor Binding Is Positively Correlated in Controls But Not in Suicides}

To test the hypothesis that, although mean receptor binding is unchanged between suicides and controls, an imbalance in binding between dopamine D1 and D2 receptors might exist in suicide, a linear regression analysis was carried out between $\left[{ }^{3} \mathrm{H}\right]$ sulpiride and $\left[{ }^{3} \mathrm{H}\right] \mathrm{SCH} 23390$ binding in individual suicides and controls. A positive correlation was found between $\left[{ }^{3} \mathrm{H}\right]$ sulpiride and $\left[{ }^{3} \mathrm{H}\right] \mathrm{SCH} 23390$ binding in controls $\left(R^{2}=0.31, p<0.05\right)$ but not in suicides $\left(R^{2}=0.00\right.$, $p=0.97$ ) (Figures $2 \mathrm{~d}$ and e). Comparison of the two correlation coefficients showed a trend toward statistical significance $(Z=1.44, p=0.07)$. This may indicate a dysregulation between dorsal striatal dopamine D1 and D2 receptor expression levels in suicide.

\section{DAT and D1 Receptor Binding in the Dorsal Striatum Decreases with Age}

Radioligand binding to DAT and the D1 receptor in the dorsal striatum decreased with increased subject age. There was a negative correlation $\left(R^{2}=0.12, p<0.05\right)$ between age and $\left[{ }^{3} \mathrm{H}\right] \mathrm{SCH} 23390$ binding across both suicides and controls, indicating loss of striatal density of D1 receptors with age (Figure 3a). Likewise, there was a negative correlation $\left(R^{2}=0.36, p<0.001\right)$ between age and $\left[{ }^{3} \mathrm{H}\right]$ mazindol binding, indicating decreased DAT availability with advancing age (Figure $3 \mathrm{~b}$ ). We observed no significant correlation between dorsal striatal $\left[{ }^{3} \mathrm{H}\right]$ sulpiride binding and age in our cohort.

\section{Dorsal Striatal DAT and D1 Receptor Binding Is Positively Correlated in Subjects Who Did Not Experience ELA}

ELA was reported in 10 suicides and 6 controls (Table 1). Because the a priori primary aim of this study was to examine the differences in striatal dopamine indices in suicide and non-suicide deaths, controls were matched to suicides for sex, age, and PMI-rather than ELA and nonELA subjects being matched for these factors. While there was no significant difference in PMI between ELA and nonELA subjects, subjects with reported ELA were significantly younger than those without reported ELA. The mean age of subjects who reported ELA was $32.7 \pm 18.4$ years while the mean age of those who did not report ELA was $56.1 \pm 18.4$ years $(t=3.82, p<0.001)$, which indicates that, in our cohort, ELA is more prevalent in younger suicides and controls. Two of the subjects with reports of ELA were females (one suicide and one control).

Because of the effect of aging on D1 and DAT striatal binding (Figure 3), it was therefore necessary to compare age-adjusted radioligand binding between ELA and non-ELA subjects. Age-corrected binding did not significantly differ between ELA and non-ELA subjects for DAT $(F=2.91, p=0.10)$, the D1 receptor $(F=0.03, p=0.87)$, or D2 receptors $(F=0.50, p=0.49)$.

To determine whether there was an imbalance in dopamine D1 and D2 receptor binding and/or dopamine receptor binding and DAT binding similar to that observed 

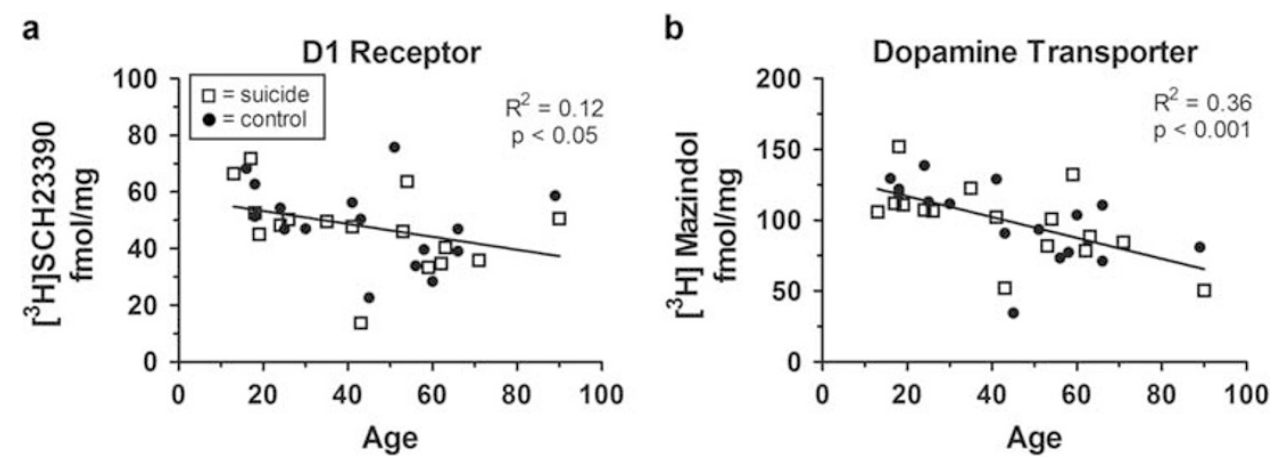

Figure 3 Loss of striatal density of DI receptors and DAT with age. (a) There is a significant negative correlation $\left(R^{2}=0.12, p<0.05\right)$ between age and $\left[{ }^{3} \mathrm{H}\right]$ SCH23390 binding across both suicides and controls. (b) Likewise, there is a significant negative correlation $\left(R^{2}=0.36, p<0.00 \mathrm{I}\right)$ between age and ${ }^{3} \mathrm{H}$ ] mazindol binding, indicating decreased DAT availability with advancing age.

a

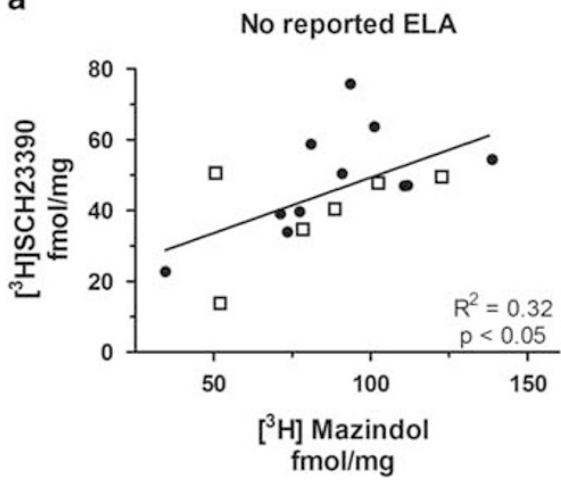

b

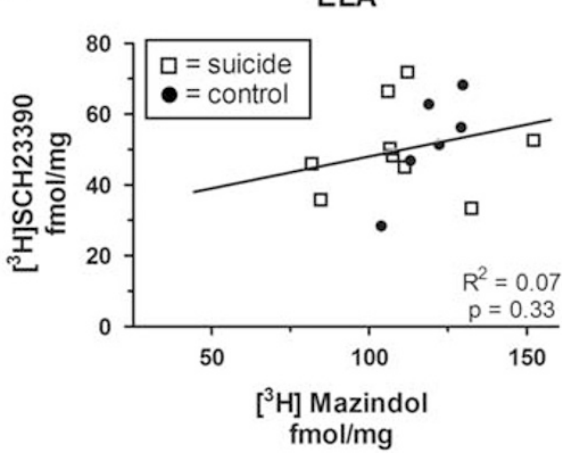

Figure 4 ELA may disrupt the equilibrium between DAT and DI receptor binding. (a) $\left[{ }^{3} \mathrm{H}\right]$ mazindol and $\left[{ }^{3} \mathrm{H}\right] \mathrm{SCH} 23390$ binding is positively correlated in subjects without reported ELA $\left(R^{2}=0.32, p<0.05\right)$ but not in (b) subjects with reported ELA $\left(R^{2}=0.07, p=0.33\right)$.

in suicide, linear regression analyses were conducted. We found a significant positive correlation between $\left[{ }^{3} \mathrm{H}\right]$ mazindol and $\left[{ }^{3} \mathrm{H}\right] \mathrm{SCH} 23390$ binding in suicides and controls without report of ELA $\left(R^{2}=0.32, p<0.05\right)$ that was not observed in subjects with reported ELA $\left(R^{2}=0.07\right.$, $p=0.33$ ) (Figure 4). The difference between correlation coefficients was not statistically significant $(Z=1.01$; $p=0.31$ ); however, this was probably a function of the limited sample size of our study.

\section{DISCUSSION}

D1, D2, and DAT radioligand binding was comparable between suicides and controls, and between those with reported ELA and those without known ELA. There was a positive correlation, however, between striatal D1 and D2 receptor binding in controls that was not present in suicides and a similar positive correlation in DAT and D1 receptor binding in non-ELA subjects that was not present in ELA subjects. Across all individuals, a decline in DAT and D1 receptor binding occurred with aging.

The absence of a difference in D1, D2, or DAT radioligand binding in the dorsal striatum of suicides as compared with controls is consistent with previous studies of striatal dopaminergic indices in MDD and suicide (Allard and
Norlen, 1997, 2001; Bowden et al, 1997; Ryding et al, 2006). However, we observed a positive correlation between dopamine D1 and D2 receptor binding in controls that was absent in suicides. A functional correlation between D1 and D2 binding has previously been reported in rodents, suggesting that levels of D1 and D2 binding are normally coordinated, perhaps through a common mechanism, in striatal tissue (Glick et al, 1988).

The loss of correlation between D1 and D2 receptor binding in postmortem striatal tissue from suicides might reflect dysregulation of dopamine receptors in suicide, perhaps as a result of previous long-term antidepressant and/or neuroleptic treatment. For example, treatment of adult male rats with antidepressant medications induces changes in D2 receptor mRNA and binding site density in the dorsolateral striatum, but does not change D1 mRNA or binding density (Ainsworth et al, 1998).

Alternatively, the dissociation of dopamine D1 and D2 receptor binding levels that we observe in suicide and MDD may reflect a decreased ability to dynamically regulate D1 and D2 receptor availability and a reduced functional link between the two receptors, similar to that reported by Seeman et al (1989) in human postmortem striatal tissue from schizophrenia and Huntington's disease. On the cellular level, an imbalance in D1 and D2 receptor availability in suicide brains could influence local and distal synaptic 
signaling mechanisms (Calabresi et al, 1992; Surmeier et al, 2007), while on the level of the individual, a dysregulation of D1 and D2 receptor balance in suicide could hold implications for antidepressant therapy (Wong and Liu, 2012). Because the majority of suicides for whom tissue was processed for both D1 and D2 radioligand binding had a diagnosis of MDD (8 of 12; Table 1), it is unclear from the current study whether an imbalance in D1 and D2 binding might be due to a unique diathesis of suicide or might be more widely observed in MDD. Inclusion of MDD subjects who died by means other than suicide would be a valuable addition for future studies.

This imbalance of dopamine D1 and D2 receptor binding in suicide could be influenced by effects of ELA on DAT and D1 equilibrium. In rodent models, early life stressors are linked to dysregulation of striatal DAT (Brake et al, 2004). Additionally, in humans, individuals with a specific haplotype in the DAT gene showed increased susceptibility to PTSD following childhood trauma (Drury et al, 2013). The observed imbalance in D1 and DAT levels in ELA-exposed subjects may not only have implications for suicide risk, but also for the developmental psychopathology of substance abuse. ELA increases risk of substance use disorders during adolescence and later life (Andersen and Teicher, 2009), and striatal dopamine has a crucial role in the rewarding pathways involved in the action of drugs of abuse and instigation of addiction (Kalivas and Volkow, 2005).

ELA was reported as more prevalent in younger suicides. ELA was determined by response during psychological autopsy, and decreased frequency of ELA report in older subjects may be due to a failure of significant others of older subjects to recall or know of adversity experienced during the subjects' youth due to the passage of time, or due to stigma of ELA leading it to be less frequently discussed in older subjects. However, it could otherwise indicate that ELA is a potentially lethal factor in vulnerability to early suicide (Johnson et al, 2002).

DAT and D1 receptor binding declined with age across suicides and controls. This is consistent with previous findings (Kemppainen et al, 2001; Rinne et al, 1990; Suhara et al, 1991; Volkow et al, 1996) and may reflect a normal age-related decline in D1 and DAT expression that is also present in MDD or suicide. Conversely, increased D1 and DAT availability in younger subjects may be one developmental factor that ultimately could contribute to a distinct psychopathology in adolescent suicide and MDD.

However, we observed no age-related decline in D2 binding using $\left[{ }^{3} \mathrm{H}\right]$ sulpiride. While some studies have demonstrated a decrease in striatal D2 binding with increasing age (Antonini and Leenders, 1993; Pohjalainen et al, 1998), which may be tied to age-related cognitive decline (Backman et al, 2000), these studies were conducted using raclopride rather than sulpiride. Studies conducted using sulpiride report either no change in striatal binding with advancing age (Memo et al, 1980) or a more subtle, subregion-specific age-related decline in caudate D2 binding (Morelli et al, 1990). These apparent differences in raclopride and sulpiride binding may in fact represent metabolic differences between in vivo and in vitro studies, as raclopride is the superior ligand for PET studies due to its greater bioavailability and brain penetration (Farde et al, 1988); considerations that are not relevant to postmortem work.
The current study provides a quantitative comparison of the density of dopamine markers DAT, D1, and D2 receptors between suicides and controls. We found no differences between suicides and controls in DAT or D1 or D2 binding, but that the balance of striatal D1 and D2 receptor binding is disrupted in suicide, and that this might be influenced by ELA. This may have implications for the etiology of suicide psychopathology or may indicate an imbalance of D1 and D2 receptors induced by ELA and/or antidepressant or antipsychotic treatment.

\section{FUNDING AND DISCLOSURE}

This work was funded by the American Foundation for Suicide Prevention, the Diane Goldberg Foundation, and NIH grants R01MH40210, P50MH62185, and T32MH20004. Dr. Mann receives royalties for the commercial use of the C-SSRS from the Research Foundation for Mental Hygiene. The authors declare no conflict of interest.

\section{ACKNOWLEDGMENTS}

We would like to acknowledge the invaluable contributions of the families of subjects involved in this study. Funding was provided by NIH grant 1P50 MH090964.

\section{REFERENCES}

Ainsworth K, Smith SE, Zetterstrom TS, Pei Q, Franklin M, Sharp T (1998). Effect of antidepressant drugs on dopamine D1 and D2 receptor expression and dopamine release in the nucleus accumbens of the rat. Psychopharmacology (Berl) 140: 470-477.

Allard P, Norlen M (1997). Unchanged density of caudate nucleus dopamine uptake sites in depressed suicide victims. J Neural Transm (Vienna) 104: 1353-1360.

Allard P, Norlen M (2001). Caudate nucleus dopamine D(2) receptors in depressed suicide victims. Neuropsychobiology 44: 70-73.

Andersen SL, Teicher MH (2009). Desperately driven and no brakes: developmental stress exposure and subsequent risk for substance abuse. Neurosci Biobehav Rev 33: 516-524.

Antonini A, Leenders KL (1993). Dopamine D2 receptors in normal human brain: effect of age measured by positron emission tomography (PET) and [11C]-raclopride. Ann NY Acad Sci 695: 81-85.

Backman L, Ginovart N, Dixon RA, Wahlin TB, Wahlin A, Halldin C et al (2000). Age-related cognitive deficits mediated by changes in the striatal dopamine system. Am J Psychiatry 157: 635-637.

Beckstead RM, Domesick VB, Nauta WJH (1979). Efferent connections of the substantia nigra and ventral tegmental area in the rat. Brain Res. 175: 191-217.

Bowden C, Cheetham SC, Lowther S, Katona CL, Crompton MR, Horton RW (1997). Dopamine uptake sites, labelled with [3H] GBR12935, in brain samples from depressed suicides and controls. Eur Neuropsychopharmacol 7: 247-252.

Brake WG, Zhang TY, Diorio J, Meaney MJ, Gratton A (2004). Influence of early postnatal rearing conditions on mesocorticolimbic dopamine and behavioural responses to psychostimulants and stressors in adult rats. Eur J Neurosci 19: 1863-1874.

Bruffaerts R, Demyttenaere K, Borges G, Haro JM, Chiu WT, Hwang I et al (2010). Childhood adversities as risk factors for onset and persistence of suicidal behaviour. Br J Psychiatry 197: $20-27$. 
Calabresi P, Maj R, Mercuri NB, Bernardi G (1992). Coactivation of $\mathrm{D} 1$ and D2 dopamine receptors is required for long-term synaptic depression in the striatum. Neurosci Lett 142: 95-99.

Dougherty DD, Bonab AA, Ottowitz WE, Livni E, Alpert NM, Rauch SL et al (2006). Decreased striatal D1 binding as measured using PET and [11C]SCH 23,390 in patients with major depression with anger attacks. Depress Anxiety 23: 175-177.

Drury SS, Brett ZH, Henry C, Scheeringa M (2013). The association of a novel haplotype in the dopamine transporter with preschool age posttraumatic stress disorder. J Child Adolesc Psychopharmacol 23: 236-243.

Dunlop BW, Nemeroff CB (2007). The role of dopamine in the pathophysiology of depression. Arch Gen Psychiatry 64: 327-337.

Enoch MA (2011). The role of early life stress as a predictor for alcohol and drug dependence. Psychopharmacology (Berl) 214: 17-31.

Farde L, Wiesel FA, Jansson P, Uppfeldt G, Wahlen A, Sedvall G (1988). An open label trial of raclopride in acute schizophrenia. Confirmation of D2-dopamine receptor occupancy by PET. Psychopharmacology (Berl) 94: 1-7.

Gerfen CR (1985). The neostriatal mosaic. I. Compartmental organization of projections from the striatum to the substantia nigra in the rat. J Comp Neurol 236: 454-476.

Glick SD, Lyon RA, Hinds PA, Sowek C, Titeler M (1988). Correlated asymmetries in striatal D1 and D2 binding: relationship to apomorphine-induced rotation. Brain Res 455: 43-48.

Jastrow TR, Richfield E, Gnegy ME (1984). Quantitative autoradiography of $[3 \mathrm{H}]$ sulpiride binding sites in rat brain. Neurosci Lett 51: 47-53.

Johnson JG, Cohen P, Gould MS, Kasen S, Brown J, Brook JS (2002). Childhood adversities, interpersonal difficulties, and risk for suicide attempts during late adolescence and early adulthood. Arch Gen Psychiatry 59: 741-749.

Kalivas PW, Volkow ND (2005). The neural basis of addiction: a pathology of motivation and choice. Am J Psychiatry 162: 1403-1413.

Kelly TM, Mann JJ (1996). Validity of DSM-III-R diagnosis by psychological autopsy: a comparison with clinician ante-mortem diagnosis. Acta Psychiatr Scand 94: 337-343.

Kemppainen N, Marjamaki P, Roytta M, Rinne JO (2001). Different pattern of reduction of striatal dopamine reuptake sites in Alzheimer's disease and ageing. J Neural Transm (Vienna) 108: 827-836.

Laasonen-Balk T, Kuikka J, Viinamaki H, Husso-Saastamoinen M, Lehtonen J, Tiihonen J (1999). Striatal dopamine transporter density in major depression. Psychopharmacology (Berl) 144: 282-285.

MacMillan HL, Fleming JE, Streiner DL, Lin E, Boyle MH, Jamieson E et al (2001). Childhood abuse and lifetime psychopathology in a community sample. Am J Psychiatry 158: 1878-1883.

Mann JJ (2000). The biology of suicide: the dimensional versus the diagnostic correlates. Eur Psychiatry 15: 278s-279s.

Meaney MJ, Brake W, Gratton A (2002). Environmental regulation of the development of mesolimbic dopamine systems: a neurobiological mechanism for vulnerability to drug abuse? Psychoneuroendocrinology 27: 127-138.

Memo M, Lucchi L, Spano PF, Trabucchi M (1980). Aging process affects a single class of dopamine receptors. Brain Res 202: 488-492.

Molnar BE, Berkman LF, Buka SL (2001). Psychopathology, childhood sexual abuse and other childhood adversities: relative links to subsequent suicidal behaviour in the US. Psychol Med 31: 965-977.

Morelli M, Mennini T, Cagnotto A, Toffano G, Di Chiara G (1990). Quantitative autoradiographical analysis of the age-related modulation of central dopamine D1 and D2 receptors. Neuroscience 36: 403-410.

Pitchot W, Reggers J, Pinto E, Hansenne M, Fuchs S, Pirard S et al (2001). Reduced dopaminergic activity in depressed suicides. Psychoneuroendocrinology 26: 331-335.

Pohjalainen T, Rinne JO, Nagren K, Syvalahti E, Hietala J (1998). Sex differences in the striatal dopamine D2 receptor binding characteristics in vivo. Am J Psychiatry 155: 768-773.

Pruessner JC, Champagne F, Meaney MJ, Dagher A (2004). Dopamine release in response to a psychological stress in humans and its relationship to early life maternal care: a positron emission tomography study using [11C]raclopride. J Neurosci 24: 2825-2831.

Przedborski S, Kostic V, Jackson-Lewis V, Cadet JL, Burke RE (1991). Effect of unilateral perinatal hypoxic-ischemic brain injury in the rat on dopamine D1 and D2 receptors and uptake sites: a quantitative autoradiographic study. J Neurochem 57: 1951-1961.

Rinne JO, Lonnberg P, Marjamaki P (1990). Age-dependent decline in human brain dopamine D1 and D2 receptors. Brain Res 508: 349-352.

Ruiz J, Gabilondo AM, Meana JJ, Garcia-Sevilla JA (1992). Increased $[3 \mathrm{H}]$ raclopride binding sites in postmortem brains from schizophrenic violent suicide victims. Psychopharmacology (Berl) 109: 410-414.

Ryding E, Ahnlide JA, Lindstrom M, Rosen I, Traskman-Bendz L (2006). Regional brain serotonin and dopamine transporter binding capacity in suicide attempters relate to impulsiveness and mental energy. Psychiatry Res 148: 195-203.

Savitz JB, Drevets WC (2013). Neuroreceptor imaging in depression. Neurobiol Dis 52: 49-65.

Seeman P, Niznik HB, Guan HC, Booth G, Ulpian C (1989). Link between D1 and D2 dopamine receptors is reduced in schizophrenia and Huntington diseased brain. Proc Natl Acad Sci USA 86: $10156-10160$.

Shen W, Flajolet M, Greengard P, Surmeier DJ (2008). Dichotomous dopaminergic control of striatal synaptic plasticity. Science 321: 848-851.

Suhara T, Fukuda H, Inoue O, Itoh T, Suzuki K, Yamasaki T et al (1991). Age-related changes in human D1 dopamine receptors measured by positron emission tomography. Psychopharmacology (Berl) 103: 41-45.

Suhara T, Nakayama K, Inoue O, Fukuda H, Shimizu M, Mori A et al (1992). D1 dopamine receptor binding in mood disorders measured by positron emission tomography. Psychopharmacology (Berl) 106: 14-18.

Surmeier DJ, Ding J, Day M, Wang Z, Shen W (2007). D1 and D2 dopamine-receptor modulation of striatal glutamatergic signaling in striatal medium spiny neurons. Trends Neurosci 30: 228-235.

Thibault D, Loustalot F, Fortin GM, Bourque MJ, Trudeau LE (2013). Evaluation of D1 and D2 dopamine receptor segregation in the developing striatum using BAC transgenic mice. PLoS One 8: e67219.

Torres GE, Gainetdinov RR, Caron MG (2003). Plasma membrane monoamine transporters: structure, regulation and function. Nat Rev Neurosci 4: 13-25.

Vallone D, Picetti R, Borrelli E (2000). Structure and function of dopamine receptors. Neurosci Biobehav Rev 24: 125-132.

Volkow ND, Ding YS, Fowler JS, Wang GJ, Logan J, Gatley SJ et al (1996). Dopamine transporters decrease with age. J Nucl Med 37: 554-559.

Wong AH, Liu F (2012). Uncoupling the dopamine D1-D2 receptor complex: a novel target for antidepressant treatment. Clin Pharmacol Ther 91: 298-302.

Xu J, Murphy SL, Kochanek KD, Bastian BA (2016). Deaths: final data for 2013. Natl Vital Stat Rep 64: 1-118. 